\title{
LUT
}

Lappeenranta

University of Technology

\section{The darker side of sustainability: Tensions from sustainable business practices in business networks}

Tura Nina, Keränen Joona, Patala Samuli

This is a Final draft version of a publication

published by Elsevier

in Industrial Marketing Management

DOI: $\quad 10.1016 / j . i n d m a r m a n .2018 .09 .002$

Copyright of the original publication: (c) 2018 Elsevier Ltd.

Please cite the publication as follows:

Tura, N., Keränen, J., Patala, S. (2018). The darker side of sustainability: Tensions from sustainable business practices in business networks. Industrial Marketing Management. DOI: 10.1016/j.indmarman.2018.09.002 
Author's final version

The darker side of sustainability:

\title{
Tensions from sustainable business practices in business networks
}

\author{
Nina Tura ${ }^{a^{*}}$, Joona Keränen ${ }^{a}$, Samuli Patala ${ }^{b}$ \\ ${ }^{a}$ School of Business and Management, Lappeenranta University of Technology, P.O. Box 20, Lappeenranta FI-53851, Finland \\ ${ }^{\mathrm{b}}$ Department of Management Studies, Aalto University School of Business, P.O. Box 11110, Aalto FI-500076, Finland \\ *Corresponding author. E-mail address: nina.tura@lut.fi
}

\begin{abstract}
While the current literature generally assumes that implementing sustainable business practices (SBPs) will lead to improved wellbeing and positive outcomes, relatively little research has explored the potential tensions and conflicts that SBPs may cause in multi-actor networks. To address this issue, we conduct a qualitative multiple case study in a regional business network, including interviews with 43 managers in 17 firms in different industries. The findings of this study identify four types of tensions (economic, structural, psychological, and behavioral) that tend to emerge when firms implement SBPs in networks, and illustrate how different stakeholders (implementers, suppliers, customers, other network partners) perceive them. Overall, this study contributes to the current literature by highlighting the underexplored "dark side" of sustainability, and illuminating how organizational decisions aiming at improving collective wellbeing can also lead to tensions and conflicts. For managers, this study offers insights into how to anticipate, manage and mitigate potential tensions that might arise in business networks when one stakeholder decides to implement a SBP.
\end{abstract}

Keywords: Sustainability, sustainable business practices, tensions, negative consequences, business networks, environmental

\section{Highlights}

- Limited research on the "dark side" of sustainability

- An embedded multiple case study with 17 firms in a regional network

- Potential tensions that may emerge as a result of implementing sustainable business practices in business networks

- How tensions are experienced by different actors in a business network 


\section{The darker side of sustainability: Tensions from sustainable business practices in business networks}

\section{Introduction}

Sustainability is considered a new strategic imperative and a longterm goal for firms, nations, and society as a whole (Finke, Gilchrist, \& Mouzas, 2016; Porter \& Reinhardt, 2007). Customers, investors and other stakeholders demand continuous improvements in environmental and social responsibility (Fearne, Garcia Martinez, \& Dent, 2012), and companies are increasingly encouraged to implement sustainable business practices (SBPs) to reduce the environmental load and to stay competitive (Johnsen, Miemczyk, \& Howard, 2017; Kotler, 2011). However, while the mainstream literature generally assumes that SBPs lead to win-win situations, we need more understanding on the potential tensions and conflicts that emerge when implementing SBPs (Hahn, Figge, Pinkse, \& Preuss, 2010; Öberg, Huge-Brodin, \& Björklund, 2012).

SBPs are generally defined as activities, initiatives or policies that aim at solving environmental and social problems while maintaining a profit (López, Garcia, \& Rodriquez, 2007; Ortiz-De-Mandojana \& Bansal, 2016; Tate, Ellram, \& Gölgeci, 2013). Driven by the need to commercialize both economically viable and societally acceptable solutions, a majority of the research in this area has focused on examining the potential benefits that economic, environmental and social actors may accrue from sustainability (e.g. Doganova \& Karnøe, 2015; Fearne et al., 2012; Patala et al., 2016; Sharma, Iyer, Mehrotra, \& Krishnan, 2010). However, given that SBPs have usually impacts that are realized in the long term and influence actors in broader business networks (Lacoste, 2016; Öberg et al., 2012; Peltola, AarikkaStenroos, Viana, \& Mäkinen, 2016; Ritvala \& Salmi, 2010), they may also lead to unexpected or even detrimental consequences that may cause tensions between the network actors (Hahn, Pinkse, Preuss, \& Figge, 2015).

Tensions are usually understood as negative consequences, such as strain and conflict, that result from contradictory goals and interests between collaborating actors, and can hamstring, aggravate or even break up business relationships and network partnerships (e.g., Fang, Chang, \& Peng, 2011; Gnyawali, Madhavan, He, \& Bengtsson, 2016). For example, investing in cleaner technologies can improve operational performance and reduce environmental load, but they are often costly and involve high risks, including uncertainties about customer needs, legislation and commercialization potential (Hall, 2002). Adopting ethical purchasing practices can improve a firm's image and social status (Porter \& Kramer, 2006), but also force other supply chain partners to change their operations or even end relationships if they cannot comply, thereby increasing mental and financial stress within a firm's network (Jackson \& Young, 2016).

Although implementing SBPs can have clearly both far-reaching and widely experienced negative consequences, "conflicts and trade-offs between economic, environmental and social aspects have received very little attention in the management literature so far" (Hahn et al., 2010, p. 218). Likewise, while recent industrial marketing literature has addressed emerging tensions in business networks (e.g., Chowdhury, Gruber, \& Zolkiewski, 2016; Tóth, Peters, Pressey \& Johston, 2018; Chou \& Zolkiewski, 2018), these studies have focused on tensions between economic and social goals, while tensions related to environmental goals remain less understood. Given that the risk for tensions in environmentally-oriented business networks seems to be particularly high (c.f., Patala, Hämäläinen, Jalkala, \& Pesonen, 2014; Scandelius \& Cohen, 2016), this study addresses the following research question: What kind of tensions may emerge when implementing SBPs in business networks, and how are they experienced by different network actors? 
To study this issue in a real-life context, we employed the multiple case study approach, and interviewed 43 managers in 17 firms that are developing new SBPs and operate in various industries in business-to-business (B2B) markets. B2B markets provide a highly relevant context for this study, because SBPs influence a broad network of actors (Wittneben, Okereke, Banerjee, \& Levy, 2012), and interaction in B2B markets involves "processes within organizations, in relationships between actors, and within a network of actors" (Jaakkola \& Hakanen, 2013, p. 49). Accordingly, this study contributes to the sustainability and industrial marketing literature by illustrating how the implementation of SBPs can lead to tensions, and how different actors (suppliers, implementers, customers, other stakeholders) in business networks experience them. From a broader perspective, this study also addresses the calls to explore the side-effects, or the "darker side" of sustainability (Johnsen \& Lacoste, 2016; Öberg et al., 2012).

The rest of the paper is organized as follows. First, we discuss why companies implement SBPs, and why this may cause tensions in business networks. After highlighting potential research gaps in the current literature, we describe our qualitative field study and present our findings. Finally, we discuss the potential implications and limitations of the study, and suggest future research areas.

\section{Literature review}

\subsection{Why do companies implement sustainable business practices?}

Sustainability has become a central part of business strategy in many firms and industry sectors (Porter \& Reinhardt, 2007). By adopting SBPs, firms aim at creating economic business benefits, reducing environmental impacts, addressing social issues, and displaying corporate responsibility to customers and other stakeholders (Fearne et al., 2012). As individual firms are expending increasing amounts of money and effort on a variety of environmental investments and sustainable R\&D activities, the general attitude towards sustainability issues has started to change slowly, seeing them as potential business opportunities instead of extra regulatory costs (Kotler 2011; Porter \& Kramer, 2011; Lubin \& Esty, 2011; Tate et al., 2013).

The main motivation for implementing SBPs stems usually from environmental laws and regulations, but to an increasing extent also from business objectives, such as profitability and improved product quality (Ranta, Aarikka-Stenroos, Mäkinen, 2018; Beise \& Rennings, 2005). Consequently, firms are investing increasingly in SBPs to achieve optimal "win-win" situations, where economic, environmental, and social benefits - often referred to as the "triple bottom line" - can be realized for relevant stakeholders and networks (e.g. Ambec \& Lanoie, 2008; Ameer \& Othman, 2012; Kurapatskie \& Darnall, 2013). In short, this usually means increased profit and differentiation power for the supplier, and reduced environmental load and increased social wellbeing for the whole network, including suppliers, customers, other stakeholders, and the society as a whole (e.g. Keränen, 2017; Patala et al., 2014; Porter \& Kramer, 2006).

While the benefits of investing in sustainability are clearly recognized in the literature, the potential costs or negative consequences that may result from implementing SBPs have received much less attention (Hahn et al., 2010; Konar \& Cohen, 2001). The current literature tends to acknowledge direct economic costs and perceived risk as the primary drawbacks of implementing SBPs, but most of these studies focus predominantly on supplier perceptions, while under-emphasizing other stakeholders (e.g. Hall, 2002; Hansen, Grosse-Dunker \& Reichwald, 2009; Nidumolu, Prahalad \& Rangaswami, 2009). Consequently, recent sustainability research has suggested that looking at the emerging tensions between network 
partners could offer a more holistic picture of the consequences perceived by multiple actors (Hahn et al., 2015)

\subsection{Sustainable value co-creation in business networks: potential for tensions}

In the industrial marketing literature, a great deal of research has argued that value emerges through collaborative activities and interaction, and is co-created when actors exchange and integrate resourcesthat contribute to solving mutual problems (Aarikka-Stenroos \& Jaakkola, 2012; Vargo \& Lusch, 2016). Value co-creation is considered to take place in broader networks or service systems, and may hence involve a diverse set of actors that have a direct or indirect influence on, and may experience the consequences of value co-creation (Gummesson \& Mele, 2010; Pinho, Beirão, Patrício, \& Fisk, 2014; Vargo \& Lusch, 2011). However, value co-creation does not always lead to positive outcomes. It can be also disruptive, and interaction between actors can lead to deteriorating and negative outcomes (Echeverri \& Skålén, 2011; Prior \& Marcos-Cuevas, 2016; Verleye et al., 2017).

While emerging research has begun to unpack the potential negative consequences of complex exchanges with economic or social goals (e.g. Plé \& Chumpitaz Cáceres, 2010; Prior \& Marcos-Cuevas, 2016; Verleye et al., 2017), several studies indicate that the potential for negative consequences is exacerbated when value co-creation involves environmental and sustainable goals as well (e.g. Doganova \& Karnøe, 2015; Reypens, Lievens, \& Blazevic, 2016). The key reasons for this include a more diverse and multi-layered set of actors and decision makers (Baraldi, Gregori, \& Perna, 2011; Seshadri, 2013), broader network(s) of stakeholders and supply chain partners (Meqdadi, Johnsen, \& Johnsen, 2017; Öberg et al., 2012), longer decision-making cycles (Ritvala \& Salmi, 2010), competing value-creating and problem-solving logics (Patala et al., 2014), and divergent or conflicting goals and interests (Doganova \& Karnøe, 2015). Thus, sustainable value co-creation in business networks seems particularly susceptible for potential negative consequences. However, while existing research has addressed why and how sustainable value co-creation can be obstructed or restrained (Finke et al., 2016; Ritvala \& Salmi, 2010), less research has addressed how the potential negative consequences of sustainable value co-creation may manifest across business networks, or how they are experienced by different stakeholders (Öberg et al., 2012; Patala et al., 2014).

Recent industrial marketing research has advocated the use of the tension perspective to explore the hurdles and impediments between multiple actors in business networks (e.g., Chou \& Zolkiewski, 2018; Chowdhury et al., 2016; Tóth et al., 2018). In brief, tensions focus on contradictory forces, objectives, or motivations with conflicting goals and interests that tend to drive relationship or network partners apart (Das \& Teng, 2000; Tidström 2014). While some tensions can have positive impacts (especially if properly managed), they are usually considered in terms of negative consequences, or more broadly as the dark side of relationships, as they can cause strain, conflict, and emotional upheaval (Fang et al., 2011).

While the previous marketing literature identifies multiple types of tension in relationships and networks, they are usually categorized broadly under structural, psychological, and behavioral tensions (Fang et al., 2011; Tidström, 2014; Pressey \& Vanharanta, 2016). Structural tensions refer to the different ways inter-organizational relationships are organized and governed within a network, and can include, for example, tensions between structural flexibility and rigidity. Psychological tensions refer to cognitive aspects, such as attitudes and perceptions of different actors in the network. Typical psychological tensions in networks may relate to issues such as (mis)trust and temporal orientations. Finally, behavioral tensions refer to actors' activities, routines and communicative practices, and may relate for example, to active or passive, or cooperative or competitive behavior (Fang et al., 2011; Tóth et al., 2018). In addition, both the marketing and sustainability 
literatures refer often to economic tensions, which usually relate to differences between an actor's value capture and appropriation logics (Hahn et al., 2010; Chou \& Zolkiewski, 2018). Overall, since tensions can emerge between multiple actors, including individuals, groups, and organizations, they offer a good analytical lens to analyze the activities, outcomes and consequences in multi-actor networks (Burton et al., 2016).

In sum, the existing literature acknowledges that sustainability issues are often broad and complex, and require an understanding of the impacts and consequences experienced and perceived in larger networks (Wittneben et al., 2012). Because clear identification of relationships and interactions between different problems, activities and consequences related to sustainability is often very difficult, they might be best understood as tensions between different network actors, who are likely to experience them differently (Hahn et al., 2010, 2015; Kumazawa, Saito, Kozaki, Matsui, \& Mizoguchi, 2009).

\section{Methodology}

To explore the potential tensions that may result from implementing SBPs, we adopted a qualitative research approach, and employed an embedded multiple case design (Scholz \& Tietje, 2002; Yin, 2014). Because the current research on the tensions of implementing SBPs is at a relatively early stage (Hahn et al., 2010; 2015; Öberg et al., 2012), a qualitative research approach is suitable to generate a deep and detailed understanding of this complex and farreaching phenomenon in a real-life setting (Corbin \& Strauss, 2015). Moreover, an exploratory research approach supports theory building from empirical insights in an under-researched area (Eisenhardt \& Graebner, 2007). By using an embedded multiple case design, we were able to explore how the implementation of SBPs influences different actors in a business network. This gave rise to a more holistic understanding of the potential tensions in a broad and more generalizable context (Halinen \& Törnroos, 2005; Yin, 2014)

\subsection{Case selection}

We used a theoretical sampling logic to identify firms that had been developing and implementing SBPs in B2B markets, and would hence provide access to empirically rich and insightful data (Eisenhardt \& Graebner, 2007). With this aim, we approached a specific regional cluster in Finland, which includes 17 firms. The cluster has a strong history of collaboration and ongoing sustainability initiatives, facilitated by regional development organizations and a collective agenda to improve regional sustainability. Conceptually, the regional network is akin to an "industrial symbiosis network", which includes separate industries with a collective aim to achieve eco-efficiency through the exchange of resources, by-products and expertise in a socially embedded and regionally constrained system (Patala et al., 2014).

The regional network in question is built around resource- and material-intensive industries, including process and metal, wood, energy, and waste technologies. These are all mature industries, and under high economic, environmental and social pressures to adopt more efficient resource and raw material bases (i.e., solar energy, waste recycling), ecologically friendlier offerings (i.e., bio-oil, digital services), and socially responsible purchasing practices (i.e., local, ethical, and sustainable procurement). In addition, the network includes several regional development organizations, which are focused on providing consulting, financing and other support for firms in this area. Conceptually, the empirical setting represents a "nested network", as the regional industry cluster operates as a larger macro-level network, which contains several smaller embedded 'nets' or business networks (c.f., Ritvala \& Salmi, 2010). 
This approach allows us to take into account the embedded nature of individual and dyadic relationships as part of a network context (Möller \& Svahn, 2006), and explore how the actions and practices of individual actors were experienced and perceived by other actors in broader networks. Fig. 1 illustrates the regional network, the industry specific sub-networks, and the embedded case companies.

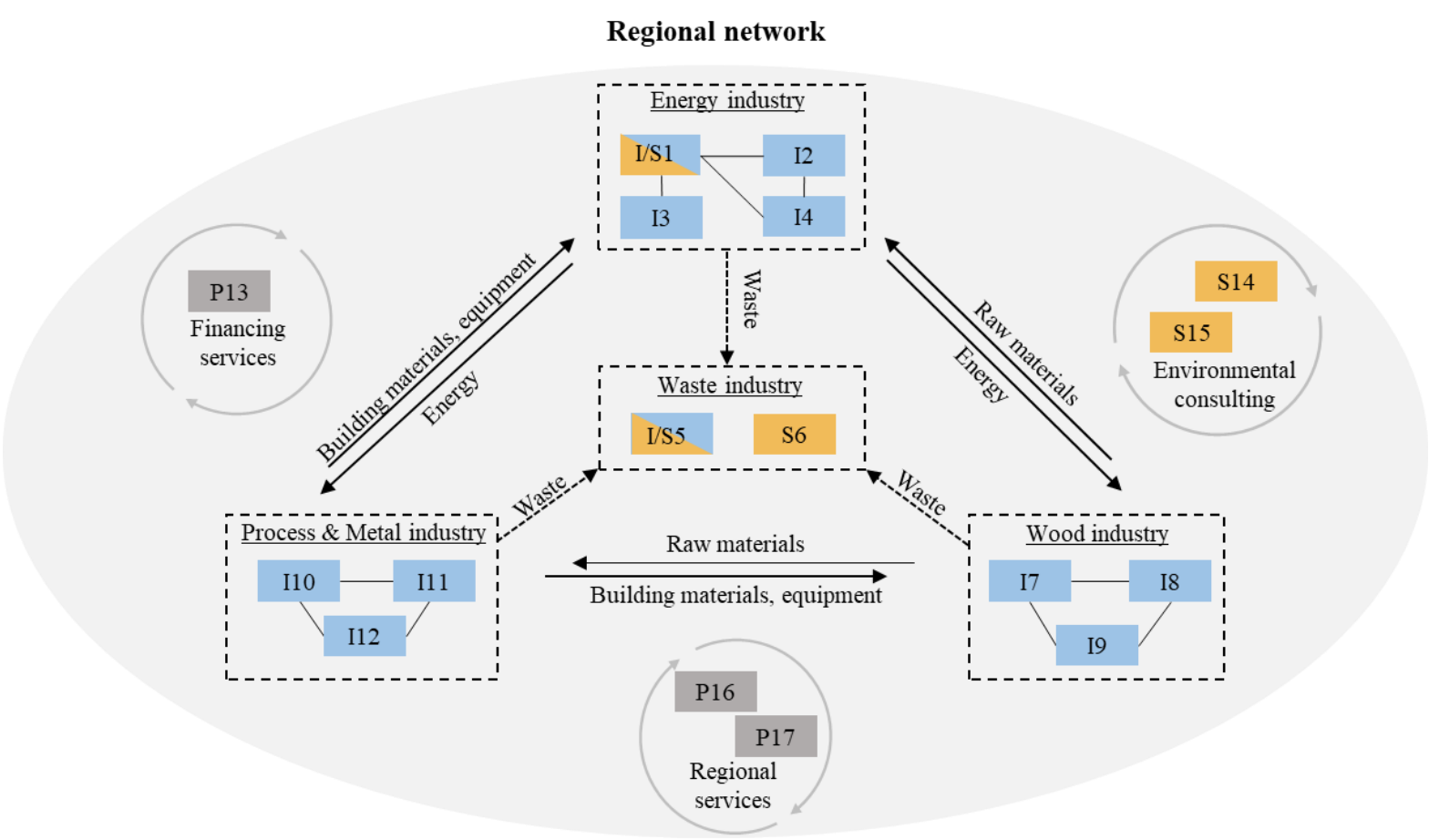

Figure 1. Illustration of the network and embedded units

The case companies represent various types of network actors and value chain positions, as they operate as suppliers and customers in their own sub-networks or network partners and stakeholders in the larger regional network. More specifically, the roles of the case companies in the regional network can be divided to three primary types: implementers (I), which have implemented new SBPs; service providers $(S)$, which have developed new services to facilitate other firms' SBPs; and regional partners $(P)$, which facilitate the adoption of SBPs in the region. In turn, the value chain positions can be considered in terms of firms who implement specific SBPs (implementers), their raw material, product, technology and energy suppliers in the "up-stream" position, their primary customers in the "down-stream" position, and other network partners providing different types of supporting services. While the firms represent specific types of network actors, they could adopt different and sometimes co-existing value chain positions, depending on their ongoing relationships with other actors. Table 1 provides an overview of the case companies, their implemented SBPs or activities employed to support other firms' SBPs, and occupied network positions in relation to other actors in the network. 
Table 1. Overview of the case companies

\begin{tabular}{|c|c|c|c|}
\hline Firm & Industry & $\begin{array}{l}\text { Implemented SBPs (I 1-11), and } \\
\text { activities that support other firms' } \\
\text { SBPs in the network (S12-P17) }\end{array}$ & $\begin{array}{l}\text { Examples of occupied network positions (in } \\
\text { addition to being an implementer for the } \\
\text { SBPs mentioned in column \#3) }\end{array}$ \\
\hline $\mathrm{I} / \mathrm{S} 1$ & $\begin{array}{l}\text { Energy } \quad \& \quad \text { heat } \\
\text { industry }\end{array}$ & $\begin{array}{l}\text { Development of bio-oil and electric } \\
\text { cars, environmental consulting, } \\
\text { commitment to } \mathrm{CO} 2 \text { free production }\end{array}$ & $\begin{array}{l}\text { Supplier for renewable energy and bio-oil } \\
\text { Network partner providing environmental } \\
\text { consulting services }\end{array}$ \\
\hline $\mathrm{I} 2$ & Energy industry & $\begin{array}{l}\text { Developing new business areas from } \\
\text { cleaner waters, investments in } \\
\text { modernizing monitoring and water } \\
\text { treatment products, responsible } \\
\text { production }\end{array}$ & $\begin{array}{l}\text { Supplier of energy and clean water products } \\
\text { Customer for environmental consulting } \\
\text { services and production equipment }\end{array}$ \\
\hline $\mathrm{I} 3$ & Energy industry & $\begin{array}{l}\text { Bio-heating plant and a transmission } \\
\text { line project }\end{array}$ & $\begin{array}{l}\text { Supplier for energy based on bio-heating } \\
\text { Customer for renewable fuels, recycled raw } \\
\text { material, production equipment and } \\
\text { environmental consulting services }\end{array}$ \\
\hline $\mathrm{I} 4$ & Energy industry & $\begin{array}{l}\text { CO2-free production, new treatment } \\
\text { plant for clean water, remote reading }\end{array}$ & $\begin{array}{l}\text { Supplier for renewable energy } \\
\text { Customer for production equipment }\end{array}$ \\
\hline $\mathrm{I} / \mathrm{S} 5$ & $\begin{array}{l}\text { Environmental \& \& } \\
\text { waste management } \\
\text { industry }\end{array}$ & $\begin{array}{l}\text { Investments in a waste incinerator and } \\
\text { business development projects related } \\
\text { to the re-use of waste, ash, and other } \\
\text { surplus material }\end{array}$ & $\begin{array}{l}\text { Supplier for recycled raw material } \\
\text { Customer for procurement equipment } \\
\text { Network partner: providing waste } \\
\text { management services }\end{array}$ \\
\hline S6 & $\begin{array}{l}\text { Waste management } \\
\text { services }\end{array}$ & $\begin{array}{l}\text { New service offering related to waste } \\
\text { information management }\end{array}$ & $\begin{array}{l}\text { Customer for energy, production equipment } \\
\text { and materials } \\
\text { Network partner providing support services } \\
\text { for waste management }\end{array}$ \\
\hline I7 & Wood industry & Bio-oil \& eco-designed products & $\begin{array}{l}\text { Supplier for bio-oil and eco-designed } \\
\text { products } \\
\text { Customer for raw material (recycled), } \\
\text { production equipment and energy }\end{array}$ \\
\hline I8 & Wood industry & Use of renewable and bio-materials & $\begin{array}{l}\text { Supplier for bio products } \\
\text { Customer for renewable fuels and energy }\end{array}$ \\
\hline I9 & Wood industry & $\begin{array}{l}\text { Bio product factory, responsible use of } \\
\text { forests, sustainable products }\end{array}$ & $\begin{array}{l}\text { Supplier for bio products } \\
\text { Customer for renewable fuels, } \\
\text { environmental consulting services and } \\
\text { energy }\end{array}$ \\
\hline $\mathrm{I} 10$ & Process industry & $\begin{array}{l}\text { Recycled fuels, commitments to } \\
\text { minimizing } \mathrm{CO} 2 \text { emissions }\end{array}$ & $\begin{array}{l}\text { Customer for environmental consulting } \\
\text { services, recycled fuels and energy }\end{array}$ \\
\hline I11 & Process industry & $\begin{array}{l}\text { Material efficiency, use of limestone- } \\
\text { based solutions }\end{array}$ & $\begin{array}{l}\text { Supplier for limestone-based products for } \\
\text { cleaning waters } \\
\text { Customer for environmental consulting } \\
\text { services and energy }\end{array}$ \\
\hline $\mathrm{I} 12$ & Steel industry & Use of recycled scrap metal & $\begin{array}{l}\text { Customer for environmental consulting } \\
\text { services }\end{array}$ \\
\hline P13 & Financing, consulting & $\begin{array}{l}\text { Focus on environmental and social } \\
\text { responsibility through digitalization }\end{array}$ & $\begin{array}{l}\text { Network partner providing financing and } \\
\text { consulting services }\end{array}$ \\
\hline S14 & $\begin{array}{l}\text { Consulting and design } \\
\text { services }\end{array}$ & $\begin{array}{l}\text { Sustainable development of processes } \\
\text { and assets, water management, } \\
\begin{array}{l}\text { construction, and environmental } \\
\text { consulting }\end{array}\end{array}$ & $\begin{array}{l}\text { Supplier for sustainable construction } \\
\text { Network partner providing environmental } \\
\text { consulting services }\end{array}$ \\
\hline S15 & Accounting services & $\begin{array}{l}\text { Offering and developing digital } \\
\text { services (replacing paper and extra } \\
\text { waste) }\end{array}$ & $\begin{array}{l}\text { Network partner providing digital services } \\
\text { to support management of business }\end{array}$ \\
\hline P16 & $\begin{array}{l}\text { Regional development } \\
\text { and consulting }\end{array}$ & $\begin{array}{l}\text { Emphasis and promotion of clean water } \\
\text { in regional development }\end{array}$ & $\begin{array}{l}\text { Network partner providing support services } \\
\text { to promote regional development }\end{array}$ \\
\hline P17 & $\begin{array}{l}\text { Regional development } \\
\text { and consulting }\end{array}$ & $\begin{array}{l}\text { Emphasis and promotion of bioenergy, } \\
\text { waste-to-energy, and wind power } \\
\text { projects in regional development }\end{array}$ & $\begin{array}{l}\text { Network partner providing support services } \\
\text { and financing to promote regional } \\
\text { development } \\
\text { Customer for waste management services, } \\
\text { environmental consulting services and energy }\end{array}$ \\
\hline
\end{tabular}




\subsection{Data collection}

The data collection for this study took place in 2014 and 2015, and involved 24 single and six group interviews with a total of 43 managers. The single interviews lasted between 35 and 109 minutes, and the group interviews between 97 and 179 minutes. All the interviews were sound-recorded and transcribed. This resulted in 984 pages of double-spaced interview transcripts. All the interviews were semi-structured, and focused on the value of sustainability, firm-specific sustainability practices, and the outcomes of these practices for firms, their customers, and stakeholders. Using a thematic guide and open-ended questions, the interviewees had the opportunity to express their ideas freely and focus on the naturally occurring issues that emerged during the interviews (Creswell, 2013). In addition, the group interviews allowed us to probe multiple views on specific issues, challenge diverging ideas, and validate emerging findings interactively (Bryman, 2012). All the interviewees were experienced senior managers, who were responsible for and/or had knowledge of the sustainability practices their firms had implemented. An overview of the interview data is presented in Table 2.

Table 2. Overview of the interview data

\begin{tabular}{|c|c|c|c|c|}
\hline Firm & Titles of informants & Interview type & $\begin{array}{l}\text { Length } \\
\text { (min) }\end{array}$ & $\begin{array}{l}\text { Number of } \\
\text { informants }\end{array}$ \\
\hline $\mathrm{I} / \mathrm{S} 1$ & $\begin{array}{l}\text { Project Manager (5x), Sales Manager (2x), Project } \\
\text { Engineer, Senior Adviser, Product Development } \\
\text { Manager, Head of IT systems, EHSQ Manager, } \\
\text { Head of International O\&M Management, Process } \\
\text { Manager, Technical Manager, Head of Division }\end{array}$ & $\begin{array}{l}\text { 5x groups } \\
\text { (groups were based } \\
\text { on organizational } \\
\text { functions/teams) }\end{array}$ & $\begin{array}{l}179 \\
97 \\
130 \\
145 \\
109\end{array}$ & 16 \\
\hline $\mathrm{I} 2$ & $\begin{array}{l}\text { Financial Director, Head of Unit, } \\
\text { Environmental Director, Unit Team Leader, } \\
\text { Environmental Manager, Project Manager }\end{array}$ & $5 \mathrm{x}$ individual & $\begin{array}{l}60,72 \\
65,52 \\
88\end{array}$ & 5 \\
\hline I3 & $\mathrm{CEO}$ & $1 \mathrm{x}$ individual & 101 & 1 \\
\hline I4 & CEO, Energy Group & $1 \mathrm{x}$ individual & 35 & 1 \\
\hline $\mathrm{I} / \mathrm{S} 5$ & $\begin{array}{c}\text { Account Manager, R\&D Manager, } \\
\text { Business Manager, Technical Manager }\end{array}$ & $4 \mathrm{x}$ individual & $\begin{array}{l}52,69 \\
94,76\end{array}$ & 4 \\
\hline S6 & Quality and Environmental Engineer & $1 \mathrm{x}$ individual & 35 & 1 \\
\hline I7 & Director, Stakeholder Relations & $1 \mathrm{x}$ individual & 72 & 1 \\
\hline I8 & $\begin{array}{l}\text { Factory Manager, Environmental Manager, } \\
\text { Communications Manager }\end{array}$ & $3 \mathrm{x}$ individual & $\begin{array}{c}35,33 \\
37\end{array}$ & 3 \\
\hline I9 & Environmental Manager & 1x individual & 94 & 1 \\
\hline $\mathrm{I} 10$ & Vice President & $1 \mathrm{x}$ individual & 109 & 1 \\
\hline I11 & Factory Manager & $1 \mathrm{x}$ individual & 68 & 1 \\
\hline I12 & $\begin{array}{c}\text { Product Development \& Technical CRM Manager, } \\
\text { Environmental Manager, } \\
\text { Process Development Manager }\end{array}$ & $1 \mathrm{x}$ group & 103 & 3 \\
\hline S13 & Head of Office & $1 \mathrm{x}$ individual & 35 & 1 \\
\hline $\mathrm{P} 14$ & Communications Manager & $1 \mathrm{x}$ individual & 45 & 1 \\
\hline S15 & Head of Office & $1 \mathrm{x}$ individual & 34 & 1 \\
\hline P16 & Development Manager & $1 \mathrm{x}$ individual & 84 & 1 \\
\hline P17 & CEO & $1 \mathrm{x}$ individual & 73 & 1 \\
\hline Total & & $\begin{array}{l}24 \text { individual and } \\
6 \text { group interviews }\end{array}$ & 2281 & 43 \\
\hline
\end{tabular}

We supplemented the primary interview data with a large set of rich secondary data. This included analyses of company websites, annual reports, specific sustainability and corporate 
social responsibility reports, as well as field notes (50 pages) of 16 steering group meetings and workshops with representatives from the regional network actors (total duration 45 hours), and notes (86 pages) of 33 meetings with a broader research group (total duration 89 hours) where emerging findings and key issues were discussed. Overall, this documentary material provided a rich information resource and insights into the SBPs implemented by different firms, as well as the consequences experienced by different stakeholders (Hill, 1993).

\subsection{Data analysis}

Given the large amount of empirical data, our analysis proceeded in three key stages. In the first stage, we employed within-case analysis and open coding, and identified specific SBPs and subsequent impacts that they generated in the network (Miles, Huberman, \& Saldana, 2014). This allowed us to understand what kind of SBPs specific firms had implemented (see Table 1 for an overview), and how their impacts were perceived by other actors in the network. At this stage, the preliminary insights indicated a substantial number of conflicting perceptions between different firms, which led us to focus on the emerging tensions between the network actors. Hence our unit of analysis was a specific tension perceived between (or within) different business network actors in their relationship.

In the second stage, we employed cross-case analysis and axial coding, and categorized the emerging tensions based on their properties and characteristics (Corbin \& Strauss, 2015). To aid our analysis and categorization, we compared the emerging findings to existing literature, and informed by previous studies on network-based tensions (e.g., Tóth et al., 2018), we extracted specific tensions to thematic categories. At this stage, we also unpacked the categories to explore how different tensions were experienced and perceived by different actors (implementers, suppliers, customers, network partners). In the third stage, we integrated all the categories into an overall preliminary framework (see Table 3), and sought feedback and confirmation for the emerging findings from the informants and other researchers.

Due to the large amount of empirical data, Nvivo software and Excel spreadsheets were used to manage and facilitate the data analysis and aid subsequent theory construction (Bazeley \& Jackson, 2013). To increase the trustworthiness and validity of the study, we employed multiple sources of primary and secondary data (data triangulation), involved several researchers in the analysis and interpretation of the findings (researcher triangulation), and presented the emerging results to managerial and academic audiences (Yin, 2014).

\section{Findings}

In this section, we report the findings of the study. First, our analysis identified 20 different types of tension that seemed to emerge when firms decide to implement SBPs in business networks. In line with prior literature (Fang et al., 2011; Toth et al., 2018), it seems that the identified tensions tend to manifest in four broader categories: economic, structural, psychological, and behavioral tensions. Second, the identified tensions seem to occur between (external) and within (internal) multiple actors, as well as within multiple level (individuals, groups, organizations). Consequently, our analysis suggests that actors in different network positions tend to perceive these tensions differently. We consider these in terms of four primary positions: implementers, suppliers, customers, and other network partners. Our findings are summarized in Table 3 , and we discuss them in detail below. 
Table 3. Potential tensions from SBPs as experienced by different network actors.

\begin{tabular}{|c|c|c|c|}
\hline & \multicolumn{2}{|c|}{ Experienced by and between } & \multirow[b]{2}{*}{ Description } \\
\hline Tension & Actor 1 & Actor 2 & \\
\hline \multicolumn{4}{|c|}{ Economic tensions } \\
\hline $\begin{array}{l}\text { 1.Higher investment, } \\
\& \text { operating, and } \\
\text { opportunity costs }\end{array}$ & $\begin{array}{l}\text { Implementer's } \\
\text { top } \\
\text { management } \\
\text { or R\&D Unit }\end{array}$ & $\begin{array}{l}\text { Implementer's } \\
\text { production } \\
\text { and sales }\end{array}$ & $\begin{array}{l}\text { Senior management or R\&D invests into sustainable } \\
\text { technologies and/or modernization of production equipment, } \\
\text { which are expensive and have long payback times. This results } \\
\text { in higher cost pressures and postponing or abandoning other } \\
\text { development projects in implementer's other units (usually } \\
\text { production, sales, or service) }\end{array}$ \\
\hline $\begin{array}{l}\text { 2. Cost of operational } \\
\text { changes }\end{array}$ & Supplier & Implementer & $\begin{array}{l}\text { Implementer demands that suppliers adapt their processes to } \\
\text { new codes of conduct or sustainability requirements }\end{array}$ \\
\hline 3.Higher prices & Customer & Implementer & $\begin{array}{l}\text { Implementers charge higher prices from customers due to cost } \\
\text { increase in their own operations }\end{array}$ \\
\hline $\begin{array}{l}\text { 4.Reduced } \\
\text { functionality and } \\
\text { performance }\end{array}$ & Customer & Implementer & $\begin{array}{l}\text { Sustainable technologies do not deliver the customer the same } \\
\text { functionality or performance as traditional technologies }\end{array}$ \\
\hline \multicolumn{4}{|c|}{ Structural tensions } \\
\hline $\begin{array}{l}\text { 5.Increased } \\
\text { monitoring and } \\
\text { controlling needs }\end{array}$ & Implementer & $\begin{array}{l}\text { Suppliers and } \\
\text { other network } \\
\text { partners }\end{array}$ & $\begin{array}{l}\text { Implementer needs to monitor and control that several actors } \\
\text { in its value chain and network follow its codes of conduct }\end{array}$ \\
\hline $\begin{array}{l}\text { 6.Dependence on key } \\
\text { suppliers }\end{array}$ & Implementer & Supplier & $\begin{array}{l}\text { Implementers fear that a dependency on a raw material that is } \\
\text { available only from specific suppliers (e.g. by-products from } \\
\text { forest industry to use in a bio heating plant) can give away too } \\
\text { much negotiation and pricing power, and make them } \\
\text { vulnerable to strong-arming and other opportunistic tactics. }\end{array}$ \\
\hline $\begin{array}{l}\text { 7.Reduced power } \\
\text { positions }\end{array}$ & Supplier & Implementer & $\begin{array}{l}\text { Suppliers that have difficulties in responding to the } \\
\text { implementer's sustainability requirements or expectations have } \\
\text { lower bargaining power, or can be phased out completely. }\end{array}$ \\
\hline $\begin{array}{l}\text { 8.Difficulties to } \\
\text { design balanced } \\
\text { network policies }\end{array}$ & $\begin{array}{l}\text { Other network } \\
\text { partner }\end{array}$ & $\begin{array}{l}\text { Entire } \\
\text { network }\end{array}$ & $\begin{array}{l}\text { Other network partners need to design regional policies that } \\
\text { would benefit stakeholders equally, but the conflicting } \\
\text { interests between multiple network actors may result in } \\
\text { policies that are unequal or favor some actors } \\
\text { disproportionately with the expense of others }\end{array}$ \\
\hline \multicolumn{4}{|c|}{ Psychological tensions } \\
\hline 9.Financial risk & Implementer & Customers & $\begin{array}{l}\text { Implementer has made significant short-term investments into } \\
\text { SBPS, while the potential benefits are uncertain and realized } \\
\text { only in the long term }\end{array}$ \\
\hline 10.Technological risk & Implementer & Customers & $\begin{array}{l}\text { New SBPs lack references and proof of performance, and the } \\
\text { implementer fears that they will not be as functional or } \\
\text { effective as traditional alternatives }\end{array}$ \\
\hline 11.Political risk & Implementer & $\begin{array}{l}\text { Government/ } \\
\text { Regulatory } \\
\text { bodies }\end{array}$ & $\begin{array}{l}\text { Implementer fears that constantly changing political decisions, } \\
\text { regulation, or legislation will affect a new SBP negatively }\end{array}$ \\
\hline $\begin{array}{l}\text { 12. Reduced } \\
\text { motivation to adhere } \\
\text { to codes of conduct }\end{array}$ & Supplier & Implementer & $\begin{array}{l}\text { Suppliers feel that they are forced to measure, monitor and } \\
\text { report sustainability indicators that are not relevant for their } \\
\text { own business }\end{array}$ \\
\hline $\begin{array}{l}\text { 13.Fear of disclosing } \\
\text { sensitive business } \\
\text { information }\end{array}$ & Customer & Implementer & $\begin{array}{l}\text { Customers are reluctant to share sustainability information and } \\
\text { data if it is business-critical or otherwise sensitive }\end{array}$ \\
\hline $\begin{array}{l}\text { 14.Greenwashing } \\
\text { concerns }\end{array}$ & Customer & Implementer & $\begin{array}{l}\text { Customer fears that the supplier's sustainability claims are } \\
\text { corporate posturing or deceptive marketing, but do not deliver } \\
\text { actual environmental or social improvements }\end{array}$ \\
\hline $\begin{array}{l}\text { 15.Defensiveness } \\
\text { against new regional } \\
\text { sustainability policies }\end{array}$ & $\begin{array}{l}\text { Other network } \\
\text { partners }\end{array}$ & $\begin{array}{l}\text { Entire } \\
\text { network }\end{array}$ & $\begin{array}{l}\text { Network actors are slow or reluctant to comprehend the } \\
\text { potential benefits and opportunities of new sustainability } \\
\text { polities }\end{array}$ \\
\hline
\end{tabular}




\begin{tabular}{|l|l|l|l|}
\hline \multicolumn{3}{|c|}{ Behavioral tensions } \\
\hline $\begin{array}{l}\text { 16.Higher disclosure } \\
\text { requirements }\end{array}$ & Implementer & $\begin{array}{l}\text { Authorities, } \\
\text { society, } \\
\text { media, }\end{array}$ & $\begin{array}{l}\text { Implementer needs to report on different sustainability criteria } \\
\text { to stakeholders, environmental and political authorities, and } \\
\text { the media }\end{array}$ \\
\hline 17.Internal resistance & $\begin{array}{l}\text { Implementer's } \\
\text { top } \\
\text { management }\end{array}$ & $\begin{array}{l}\text { Implementer's } \\
\text { field } \\
\text { personnel }\end{array}$ & $\begin{array}{l}\text { Employees are reluctant to learn new skills, accept new } \\
\text { responsibilities or process changes, and adopt new work } \\
\text { practices }\end{array}$ \\
\hline $\begin{array}{l}\text { 18.Increased need to } \\
\text { collect and share data }\end{array}$ & Supplier & Implementer & $\begin{array}{l}\text { Implementers expect the suppliers to collect and share } \\
\text { sustainability-related data about their operations and processes }\end{array}$ \\
\hline $\begin{array}{l}\text { 19.Higher } \\
\text { maintenance needs }\end{array}$ & Customer & Implementer & $\begin{array}{l}\text { Customer needs to maintain or replace environmentally- } \\
\text { friendly components more often than traditional alternatives }\end{array}$ \\
\hline $\begin{array}{l}\text { 20.Divergent } \\
\text { communication and } \\
\text { promotion needs }\end{array}$ & $\begin{array}{l}\text { Other network } \\
\text { partners }\end{array}$ & $\begin{array}{l}\text { Entire } \\
\text { network }\end{array}$ & $\begin{array}{l}\text { Other network partners need to communicate and promote } \\
\text { goals and agendas that facilitate several actors' interests and } \\
\text { objectives, which are often conflicting and contradictory }\end{array}$ \\
\hline
\end{tabular}

\subsection{Economic tensions}

Economic tensions refer to conflicts between cost allocations, and these appeared most frequently in our data. Economic tensions involved expectations or demands from one actor for other actors to invest or expend costs into technologies, processes or new practices that would be aligned with specific SBPs. However, the other actors perceived these expectations sometimes as asymmetric or unfair, and believed that they restricted their own operations.

For firms that implemented SBPs in the regional network, economic tensions manifested usually as higher investment, operating, and opportunity costs. These were often perceived internally, between different departments or functions at the implementer's organization. For example, several firms had increased their research and development budgets $(\mathrm{I} 1 ; \mathrm{I} 10)$, or invested into new environmentally friendly or modernized technologies (II3;I4;I7;I8;I9;I11), at the expense of postponing, freezing, or sometimes completely abandoning efforts to develop or expand their current sales, service, or production organizations.

\footnotetext{
"Compared to a situation where we don't have to think about sustainability, of course it brings costs. Investments have been huge (e.g. filter plant of the smelter), energy is used and waste is created. We have continuous maintenance targets and expenses... If we didn't care about sustainability, we wouldn't need environmental executives sitting here, doing paperwork and paying license fees, these are all indirect costs. "(I9)
}

For suppliers, in our sample, economic tensions manifested primarily as high costs of operational changes due to the need to accommodate increased compliance requirements from the implementing firms. In the data, such requirements ranged from improving production and operational processes to reduce emissions and carbon footprints (I1;I2;I7;S14) to educating, training and hiring new people (I2;I7) to gain different environmental and social certificates. While the requested changes aimed to improve the implementers own as well as their value chains' societal impact, several suppliers pointed out that for them the changes involved often expensive process modifications, which were seldom fully recoupable. Many suppliers noted they had faced costly sustainability requirements from their business partners, and felt it was usually easier to comply by accepting short-term costs than risk losing valuable partners and long-term business potential.

“Our partners had to develop also new skills and operations through investments.” (I7)

For customers, economic tensions manifested primarily as higher prices and decreased functionality. Customers felt that when their suppliers had implemented SBPs, this had resulted in higher prices but not necessarily any improvement in actual product performance. In contrast, some customers noted actually that sometimes the sustainable components in 
purchased products or systems required more maintenance or had shorter life cycles, reducing the overall functionality and performance of the equipment.

"Customers would like to use domestic fuels instead of foreign fuels because of their lower environmental impacts. But if the price for foreign fuel is lower, they will unfortunately select that." (I2)

\subsubsection{Structural tensions}

Structural tensions refer to the need for and balance of coordination and governance of vertical and/or horizontal relationships with stakeholders. For firms that implemented specific SBPs, structural tensions manifested usually as increased monitoring and controlling requirements to their value chain and network. This involved the need to manage both wider stakeholder networks and longer (up- and downstream) value chains, where several stakeholders had different, yet collective impact on the realization of the benefits from specific SBPs. However, since individual stakeholders had usually different perceptions and measures for sustainability (i.e. NOx and $\mathrm{CO} 2$ emissions vs. carbon and water footprints), a higher number of stakeholders made monitoring and controlling overall sustainability impacts often very difficult.

\footnotetext{
"We should pay more attention to our value chain. There are weak points for sure ...Although our suppliers are the most reliable in the field, we don't check these issues until at the last point.... Value chains are long and we don't have resources for that.... We can't say for sure whether they are using for example child labor. It's an unknown field for us and may carry threats." (I9)
}

In addition, some firms felt that implementing SBPs led to increased dependency on key suppliers who had a dominant or sole provider status for critical materials, such as raw materials for bio-heating (I3), or limestone (I8). In these cases, implementers feared that sole suppliers might leverage their unique position to increase prices, regulate supply, or otherwise influence contract conditions. On the other hand, some of the supplier firms in our sample perceived the structural tensions as reduced power positions, if they did not have enough resources or knowhow to respond to the sustainability requirements posed by the implementer, or if they declined to accommodate the implementer's compliance requirements. For example, the suppliers in the forest and energy industry had faced the risk and pressure of decreasing purchasing volumes and lowering prices if they could not adapt their processes and practices to match the implementers' sustainability expectations or demands better.

For customer firms, the data indicated no significant structural tensions. For other network partners, the structural tensions manifested usually as difficulties to design balanced network policies. For example, the regional agencies explained that since SBPs influenced several stakeholders across networks, they were under a pressure to design regional policies and practices that would try to take each stakeholder's interests and goals into account. However, due to different, and often conflicting interests within the network, it was not clear whether the agencies' lobbying efforts resulted in balanced and equally fair policies for all the network actors, or uneven agendas that disproportionally favored some, with the expense of others.

\footnotetext{
"Customers are obligated to sort their wastes in more detail. We do a lot of competitive bidding, but it is hard to include all the conditions and measurements of sustainability and environment into these tenders. There are so many things to be taken into account, and it is not clear how the evaluation and scoring of these indicators would be fair for both new and old players in the waste business." (S6)
}

\subsubsection{Psychological tensions}


Psychological tensions refer to changes in emotions, attitudes, motives and feelings, caused primarily by the added uncertainty associated with SBPs (Slawinski et al. 2015). For sample firms that implemented specific SBPs, psychological tensions manifested primarily as increased financial, technological, and political risks. For example, it was often difficult to calculate the return on investment for sustainable technologies, and many firms had risked a decrease in short-term profitability for potential but uncertain long-term business benefits. Similarly, many implementers worried about whether the new SBP would become "accepted" or "new standard" in the market, or just an inferior alternative to traditional technologies. Finally, the implementers were also highly concerned about political decisions, such as support or taxation policies for biofuel, coal, or other sources of renewable energy (I1;I3;I10), and the enactment of emissions and chemicals regulations (I8-10;I12), which have a major influence on the business potential of sustainable products and services.

\footnotetext{
"We cannot yet put a value on the sustainability investments in peat production. ... When we decided to make investments, we did not calculate our expectations for business sales. We see it more as a long-term investment in future business possibilities." (I7)

"There's political risk. As the fuel business is based on politics in the EU, there is a risk of changing regulations. Authorities may ruin everything." (I10)

\begin{abstract}
"The drivers of sustainability come from politics, and involve risks as to whether they will be in line with our current decisions in the future... it may result in some administrative decisions that have negative effects for us. It's a little terrifying." (I3)
\end{abstract}

For some of the supplier firms, psychological tensions manifested as reduced motivation to adhere to the implementer's codes of conduct, especially if these had no direct benefits to the supplier, or if the value chain involved other partners who did not follow similar practices. Several suppliers noted that it was relatively common for their value chain partners to lobby for regulations and/or request sustainability policies that favored individual actors unequally. This often reduced the suppliers' willingness to comply, at least when it required significant changes or cost allocations.

\footnotetext{
"Our industry doesn't market much in "being green". There are certain actors that are intentionally quiet about this." (I9)

"There are multiple interest levels among actors contributing to sustainability regulations. The interest in these issues may arise purely from gaining competitive advantage over other actors" (I12)
}

For customer firms, psychological tensions manifested primarily as a fear of disclosing sensitive information about their processes and operations. Customers pointed out that suppliers were increasingly requesting access to their process and usage data to analyze the potential sustainability impacts of their offerings, and this involved business-critical information, which customers were often reluctant to share. Furthermore, some customers noted also that without careful diligence and supplier evaluation, they had sometimes concerns about greenwashing, or in other words, whether the supplier's SBPs actually had the promised impacts, or were just corporate posturing and empty environmental claims.

\footnotetext{
"In management we may see responsibility in a different way.... For example, we have had to close factories. For some, these actions may seem unresponsive, but from company perspective this is economic sustainability...[but] society may criticize and have different opinion. That may increase local negative effects and labor disruptions, and increase risks related to delivery reliability from the eyes of the customer." (I7)
}

For other network partners, psychological tensions manifested primarily as defensiveness against new regional sustainability policies. For example, the regional agencies noted that the business actors in the area were usually very resistant or slow to 
adopt and assimilate new sustainability initiatives, unless they had a direct impact on their business.

\begin{abstract}
"Of course there are customers that do not want to give up paper... These types of customers cover still 55-60\%. It is hard work to get them to understand our system and online services". (S15)

"SMEs are not very interested in sustainability goals at the broader, global level. Very often they will just have a defensive reaction, like "we get these new things every day, how is this relevant to us?"(P16)
\end{abstract}

\title{
4.1.4 Behavioral tensions
}

Behavioral tensions refer to changes in operational or communicative behaviors within a business network (Toth et al. 2017). From the sustainability perspective, new activities and practices for analyzing sustainability impacts and reporting to stakeholders can cause considerable behavioral changes and require extra resources (Greenwood et al. 2015). For firms that implemented specific SBPs, behavioral tensions manifested primarily as increased disclosure requirements, as they had to report on different sustainability criteria not only to environmental and political authorities, but to potential customers and network partners as well. Many of them also noted that increased workload, bureaucracy, training, and social pressure related to implementing SBPs often led to internal resistance within their organizations. For example, the implementers described situations and behaviors where internal resistance ranged from skepticism, lack of commitment and negative attitudes to misunderstanding or disregarding responsibilities intentionally, and barriers between field organizations and top management.

\footnotetext{
"Much of the time is spent answering the many questions of people, claims coming from water protection associations, media contacts and reviews ... We have promised to measure every bog separately, but the information on the impacts on the environment is not particularly accurate ... So the actions we are performing now may be a bit pointless, but we have to do so to gain social acceptance." (I2)

"The workload of the personnel and their mental wellbeing are negative issues related to sustainability. Investing in sustainability has brought extra work, required many working hours, development and planning activities...The commitments that we made raised considerable resistance inside the company." (I7)
}

For supplier firms in our study, the behavioral tensions manifested primarily as an increased need to collect and share sustainability-related data and information about their operations and processes with the implementer. While the suppliers generally understood the need for additional communication efforts, many felt that they were being forced to measure, monitor, and report sustainability indicators that have little effect on their business practices.

\footnotetext{
"Increasing public awareness raises certain tough questions for us to answer, although they may not have anything to do with us." (I9)

"In addition to other work, sustainability means more monitoring efforts and extra work ... Customers are expecting certain things, but in reality, the time spent on designing and planning may be longer, bringing negative consequences in terms of work." (S14)
}

For customer firms, the behavioral tensions manifested as higher maintenance needs, as the sustainable technologies and/or components they purchased had to be maintained, replaced or upgraded more often than traditional alternatives. For example, in the case of bio-energy power plants, when the customers burned recycled waste material, this eroded their production equipment (I1). In addition, when customers replaced cement with more renewable (woodbased) materials in the construction process, they experienced increased maintenance requirements and lower life-cycles of buildings (I4). 
"There is a big debate about the facts of using wood vs. cement -based materials in construction related to [sustainability] impacts and life-cycle maintenance." (I4)

For other network partners, behavioral consequences manifested primarily as divergent communication and promotion needs, because of the diverse goals and interests of different network actors. For example, the forest industry wanted to promote wood as a renewable material source for construction, while the process industry wanted to highlight the long lifecycle of concrete- and steel -based materials instead. Furthermore, while the private organizations in the area wanted to reduce $\mathrm{CO} 2$ emissions only to levels that would have a minimal impact on production to optimize or protect sales and profits, the public organizations wanted to maximize the reduction in overall $\mathrm{CO} 2$ emissions. Several network partners had to navigate this riptide, and choose how to stretch and allocate resources to promote a host of conflicting sustainability goals simultaneously.

\footnotetext{
"We have divergent interests inside Finland. All actors want to support their own interest areas, and this may have negative effects on others." (I12)
}

\section{Discussion and Conclusions}

In this study, we have explored the potential tension that may result from implementing SBPs in business networks. Network partnerships and joint action are important drivers of sustainability goals (Ritvala \& Salmi, 2011; Patala et al., 2014), and it is critical to understand how to minimize the costs and barriers of collaboration. This is an important issue, as industrial firms are investing increasingly in various SBPs, but their potential "dark side" effects remain under-researched (Hahn et al., 2010). Our findings illustrate why and how the implementation of SBPs may lead to emerging tensions, and how different actors in a network setting in business markets experience them. Next, we consider the implications of our findings by comparing the tensions experienced at different network positions and suggest some potential strategies for decreasing the tensions.

As demonstrated by the findings, if one network partner adopts new sustainability practices, this may generate tensions in its business network. We found that tensions inside the implementer's organization were typically related to budgetary tensions among different business units and functions, as well as the potential internal resistance to change by employees, which were predominantly economic or behavioral by nature. These tensions seemed to be especially dependent on the type of SBP undertaken, as more technologyintensive SBPs are likely to involve higher costs and risks. These tensions could be decreased by higher involvement of different functions and internal personnel, as SBPs, which are integrated with the core business functions, have typically higher potential benefits (Halme \& Laurila, 2010).

The tensions between implementers and their suppliers, in turn, are often related to the supplier's capability to meet new sustainability criteria introduced by SBPs, and a potential fear of being relegated to a lower tier supplier if the sustainability criteria are not met. Structural tensions were particularly evident between the supplier and implementer. These tensions seemed to be influenced by the cultural and power distance (Meqdadi et al. 2017) between the implementer and the supplier, and may be especially prevalent in global supply chains, leading to considerably different perceptions of sustainability. An implementer could decrease this tension by investing in training and education activities with the suppliers, to help meet their sustainability goals. For example, previous research has shown that more collaborative and inclusive strategies of involving suppliers in SBPs are more sustainable in the long run compared to dictatorial initiatives driven by the implementer (Drake \& Schlacter, 2008; Hoejmose, Brammer, \& Millington, 2012). 
The tensions between implementers and customers were largely related to concerns about increasing prices, decreasing performance or potential concerns with greenwashing. These tensions seemed to be higher for SBPs involving substantial change in product design, and they were usually psychological and economic by nature. These types of tensions might be mitigated by conducting a deeper value assessment about the new value potential that the SBP will realize to the customers or their stakeholders (Keränen \& Jalkala, 2013; Patala et al. 2016). The implementer could also offer additional services and training to accommodate with the changes in the offering caused by the SBP.

Finally, the tensions between implementers and other network partners were often related to the added network complexity as a result of SBPs, as more diverse stakeholder needs and plurality of values needed to be incorporated into the network activities. We found tensions between implementers and other network partners equally in all of the four categories. These tensions are likely to be stronger when the number and heterogeneity of stakeholders increases. An implementer could address these by investing in open stakeholder communication and their higher involvement within the network. The increased involvement of new stakeholders as a result of SBPs may open new opportunities for other network partners, as the "value space" of the network increases (Reypens et al. 2016; Halme \& Laurila, 2009).

\subsection{Theoretical implications}

Collectively, the findings of this study offer three main contributions. First, previous sustainability literature has focused primarily on the benefits and/or positive consequences that result from implementing SBPs, but with limited attention to potential costs and negative consequences (Konar \& Cohen, 2001; Hahn et al., 2010). This study has addressed this gap in the sustainability literature by highlighting the potential conflicts and tensions, or more broadly, the "dark side" of sustainability (Johnsen \& Lacoste, 2016) that may result from implementing SBPs in business networks. Our findings illustrate how different sustainability initiatives, despite stakeholders' best intentions, can also lead to perceived strain and conflict between actors, which we have conceptualized as tensions (Fang et al., 2011; Gnyawali et al., 2016). This responds to recent calls that advocate tensions as a suitable lens to analyze the consequences of SBPs at multiple levels (Hahn et al., 2015). Our findings identify four types of tensions (economic, structural, psychological, and behavioral) that tend to manifest in a firm's network because of implementing SPBs, and illustrate how different network actors perceive them. This responds to the calls to increase understanding on how different stakeholders in business networks experience and perceive the impacts of SBPs (e.g. Lacoste, 2016).

Second, the findings contribute to the contemporary industrial marketing literature, which considers how negative value perceptions emerge from interaction and collaboration (e.g. Prior \& Marcos-Cuevas 2016; Verleye et al., 2017). While recent research indicates that negative value perceptions might be particularly prevalent in sustainable business networks, which are usually characterized by multiple actors, goals, and interests (e.g., Oruezabala \& Rico, 2012; Scandelius \& Cohen, 2016), most of the previous studies in this area have been limited to single case studies and dyadic/triadic settings (Echeverri \& Skålen, 2011; Chowdury et al. 2016; Makkonen \& Okkonen, 2018). By employing a multiple case design, this study offers a rich empirical account of the potential tensions that may emerge and manifest when firms adopt SBPs in broader networks with several stakeholders, and responds to calls to explore negative value perceptions in multi-actor contexts (Prior \& Marcos-Cuevas 2016; Tóth et al., 2018). Furthermore, whereas prior studies have considered misalignment in economic or social goals as the main source of tensions and conflict (Corsaro 2015; Prior \& Marcos-Cuevas 
2016), this study illustrates how intra- and/or inter-firm misalignments related to environmental goals may lead to tensions and negative value perceptions.

Thirdly, this study contributes to the literature on sustainability networks (e.g. Johnsen et al. 2017; Meqdadi et al. 2017). While previous research has shown that the resources and relations of networks can act as enablers and offer considerable advantages for sustainability practices (Patala et al. 2014; Lacoste, 2016), our research highlights networks as a potential source of inertia. Even firms that may see themselves as forerunners and attempt to go beyond regulatory compliance in their sustainability practices may find themselves constrained by the potential negative impacts on their network partners. Organizations are to a great degree a product of the networks they are embedded in (Padgett \& Powell, 2012), and thus it is important for firms to consider the network constraints when planning and implementing new SBPs, to limit the harm to existing relationships. Alternatively, firms might choose to develop new relations if goal alignment with existing partners is not possible.

\subsection{Managerial implications}

From the managerial perspective, this study sheds light on the potential tensions and negative value experiences that may emerge as a result of adopting SBPs in business markets. This may help managers understand better why, despite good intentions and collective goals, sustainability investments may become costly, face social resistance, or even fail due to insufficient stakeholder support.

For supplier firms, the findings highlight the importance of analyzing sustainability investments beyond financial costs. A more holistic evaluation of the potential economic, structural, psychological and behavioral tensions provides a basis for more inclusive costbenefit analyses, and a greater chance of successful sustainability practices. Moreover, by understanding the potential sources of negative customer and stakeholder experiences when adopting SBPs, managers may be able to anticipate, reduce, or mitigate potential tensions and conflicts, and reduce the friction between stakeholders.

For customer firms and network partners, the findings highlight the importance of careful assessment of suppliers' sustainability practices. While complying with the new sustainability requirements may result in higher prices or social discomfort in the short term, it may offer potential for improved brand equity, legitimacy and differentiating power in the long term. By understanding the sources and nature of potential tensions stemming from suppliers' sustainability practices, individual partners may increase their tolerance for short-term degradations in the process of delivering economic and social gains, and thus reduce the barriers that would prevent collective networks from realizing the benefits in the long term.

For policymakers, the findings highlight the importance of understanding the impacts of regulations, legislation and sustainability policies in broader networks and value chains. While environmental regulations often aim at influencing individual suppliers - for the collective good - they may have negative spillovers for societal wellbeing, for example in the form of decreased competitiveness, lower employment or carbon leakage due to relocations. Better understanding of the collectively experienced tensions would provide a basis for regulations and policies that would cause less friction and support the optimization of wellbeing for a broader set of stakeholders, such as societies and economies as a whole.

\subsection{Limitations and avenues for future research}

Given that this study is exploratory by nature, and based on a limited number of firms, it has natural limitations, some of which open up also potential avenues for future research. First, the study was limited largely to firms operating in resource- and material-intensive industries. Future research could investigate firms in other industries to reveal alternative tensions in 
adopting SBPs, and increase the generalizability of the results. From the theory development perspective, one important avenue would be to develop a theory and propositions that would explain how and when specific SBPs lead to particular types of tensions between specific network actors.

Second, given the emphasis on conflicting perceptions between actors in the regional network, this study conceptualized tensions as negative consequences that result from contradictory goals and interests between collaborating actors. While this approach addressed an underexplored area the current literature, it might have neglected insights on the positive consequences that adopting SBPs in networks might have. Hence, future research could provide a complementing perspective by focusing on networks where different actors have more congruent goals and aligned interests, and explore how and when SBPs result in synergies and enhanced value outcomes between network actors.

Third, this study employed qualitative field data. Future research could employ quantitative studies, and explore how different negative tensions actually impact a firm's performance or the perceived relationship quality with customers or other network partners. Moreover, a quantitative approach could define indicators that measure the potential tensions, and investigate how potential moderators such as the scope, scale, and type of different SBPs influence these tensions. In other words, how the tensions from investments in smaller versus larger, or environmentally versus socially dominant SBPs differ from each other.

Fourth, the field interviews involved a relatively large and uneven spread of informants between firms. While this is a fairly accepted practice in interpretative research that aims to generate a broader understanding of a selected phenonemon by increasing the number of cases (e.g., Eisenhardt \& Graebner, 2007), it can also result in bias that favor the perceptions of firms with more informants. On the other hand, using single informants in most of the interviewed firms offers limited possibilies to explore how tensions from SBPs are perceived at different levels or in different functions. Consequently, future research could approach multiple informants in several organizations, and explore if, how and why the perceptions of SBP might vary between different organizational levels and functions.

Finally, although this study employed a multiple case setting and a two-year research collaboration with the participating companies, it provides a relatively static analysis of the experienced and perceived tensions in business networks. An interesting avenue for future research would be to employ a longitudinal research setting, and investigate how different tensions evolve and spread over networks, and in turn, how different actors, individually and collectively, try to avoid or mitigate them over time. 


\section{References}

Aarikka-Stenroos, L., \& Jaakkola, E. (2012). Value co-creation in knowledge intensive business services: A dyadic perspective on the joint problem solving process. Industrial Marketing Management, 41(1), 15-26.

Ambec, S., \& Lanoie, P. (2008). Does it pay to be green? A systematic overview. Academy of Management Perspectives, 22, 45-62.

Ameer, R., \& Othman, R. (2012) Sustainability practices and corporate financial performance: a study based on the top global corporations. Journal of Business Ethics, 108, 61-79.

Baraldi, E., Gregori, G.L., \& Perna, A. (2011). Network evolution and the embedding of complex technical solutions: The case of the Leaf House network. Industrial Marketing Management, 40, 838-852.

Bazeley, P. \& Jackson, K. (2013). Qualitative data analysis with NVivo. Sage, London.

Beise, M. \& Rennings, K. (2005) Lead markets and regulation: a frameworks for analyzing the international diffusion of environmental innovations. Ecological Economics, 52, 5-17.

Bryman, A. (2012). Social research methods, Oxford University Press.

Burton, J., Story, V., Zolkiewski, J., Raddats, C., Baines, T.S. \& Medway, D. (2016). Identifying Tensions in the servitized value chain: If servitization is to be successful, servitizing firms must address the tensions the process creates in their value network. Research-Technology Managagement, 59(5), 38-47.

Chou, H-H., \& Zolkiewski, J. (2018). Coopetition and value creation and appropriation: The role of interdependencies, tensions and harmony. Industrial Marketing Management, Forthcoming.

Chowdhury, I. N., Gruber, T., \& Zolkiewski, J. (2016). Every cloud has a silver lining: Exploring the dark side of value co-creation in B2B service networks. Industrial Marketing Management, 55, 97-109.

Corbin, J., \& Strauss, A.L. (2015). Basics of qualitative research: Techniques and procedures for developing grounded theory. 4rd ed. Newbury Park, CA: Sage.

Corsaro, D. (2015). Negative aspects of business relationships for resource mobilization. Australasian Marketing Journal, 23, 148-154.

Creswell, J. W. (2013) Qualitative Inquiry and Research Design. Choosing Among Five Approaches. Third edition. Sage Publications, Inc.

Das, T. K., \& Teng, B. S. (2000). Instabilities of strategic alliances: An internal tensions perspective. Organization science, 11(1), 77-101.

Doganova, L., \& Karnøe, P. (2015). Building markets for clean technologies: Controversies, environmental concerns and economic worth. Industrial Marketing Management, 44, 2231.

Drake, M.J., \& Schlachter, J.T. (2008). A Virtue-Ethics Analysis of Supply Chain Collaboration. Journal of Business Ethics 82, 851-864.

Echeverri, P., \& Skålén, P. (2011). Co-creation and co-destruction: A practice-theory based study of interactive value formation. Marketing Theory, 11(3), 351-373.

Eisenhardt, K. M., \& Graebner, M. E. (2007). Theory building from cases: Opportunities and challenges. Academy of Management Journal, 50(1), 25-32. 
Fang, S.-R., Chang, Y.-S., \& Peng, Y.-C. (2011). Dark side of relationships: A tensions-based view. Industrial Marketing Management, 40(5), 774-784.

Fearne, A., Garcia Martinez, M., \& Dent, B. (2012). Dimensions of sustainable value chains: implications for value chain analysis, Supply Chain Management: An International Journal, 17(6), 575 - 581.

Finke, T., Gilchrist, A., \& Mouzas, S. (2016). Why companies fail to respond to climate change: Collective inaction as an outcome of barriers to interaction. Industrial Marketing Management, 58, 94-101.

Gnyawali, D., Madhavan, R., He, J., \& Bengtsson, M. (2016). The competition-cooperation paradox in inter-firm relationships: a conceptual framework. Industrial Marketing Management, 53, 7-18.

Greenwood, R. G., Hinings, C. R., \& Jennings, P. D. (2015). Sustainability and organizational change: An institutional perspective (pp. 323-355). An Organizational Perspective: Leading sustainable Change.

Gummesson, E., \& Mele, C. (2010). Marketing as value co-creation through network interaction and resource integration. Journal of Business Market Management, 4(4), 181198.

Hahn, T., Figge, F., Pinkse, J., \& Preuss, L. (2010). Trade-Offs in corporate sustainability: You can't have your cake and eat it. Business Strategy and the Environment, 19, 217-229

Hahn, T., Pinkse, J., Preuss, L., \& Figge, F. (2015) Tensions in Corporate Sustainability: Towards an Integrative Framework. Journal of Business Ethics, 127, 297-316.

Halinen, A. \& Törnroos, J.-A. (2005) Using case methods in the study of contemporary business networks, Journal of Business Research, 58(9), 1285-1297.

Hall, J. (2002) Sustainable development innovation: A research agenda for the next 10 years. Journal of Cleaner Production, 10, 195-196.

Halme, M., \& Laurila, J. (2009). Philanthropy, Integration or Innovation? Exploring the Financial and Societal Outcomes of Different Types of Corporate Responsibility. Journal of Business Ethics 84, 325-339.

Hansen E. G., Grosse-Dunker, F., \& Reichwald, R. (2009). Sustainability innovation cube - a framework to evaluate sustainability-oriented innovations. International journal of Innovation Management, 13(4), 683-713.

Hill, M. R. (1993). Archival strategies and techniques. London: Sage.

Hoejmose, S., Brammer, S., \& Millington, A. (2012). "Green" supply chain management: The role of trust and top management in B2B and B2C markets. Industrial Marketing Management, 41(4), 609-620.

Jaakkola, E., \& Hakanen, T. (2013). Value co-creation in solution networks, Industrial Marketing Management, 42, 47-58.

Jackson, L. \& Young, L. (2016). When business networks "kill” social networks: A case study in Bangladesh. Industrial Marketing Management, 58, 148-161.

Johnsen, R.E. \& Lacoste, S. (2016). An exploration of the 'dark side' associations of conflict, power and dependence in customer - supplier relationships. Industrial Marketing Management, 59, 76-95. 
Johnsen, T.E., Miemczyk, J., \& Howard, M. (2017). A systematic literature review of sustainable purchasing and supply research: Theoretical perspectives and opportunities for IMP-based research. Industrial Marketing Management, 61, 130-143.

Keränen, J., \& Jalkala, A. (2013). Towards a framework of customer value assessment in B2B markets: An exploratory study. Industrial Marketing Management 42, 1307-1317.

Keränen, J. (2017). Towards a broader value discourse: Understanding sustainable and public value potential. Journal of Creating Value, 3(2), 1-7.

Konar, S. \& Cohen M.A. (2001). Does the market value environmental performance? The Review of Economics and Statistics, 83(2), 281-289.

Kotler, P. (2011). Reinventing marketing to manage the environmental imperative. Journal of Marketing, 75, 132-135.

Kumazawa, T., Saito, O., Kozaki, K., Matsui, T. \& Mizoguchi, R. (2009). Toward knowledge structuring of sustainability science based ontology engineering. Sustainability Science, 4, 99-116.

Kurapatskie, B. \& Darnall, N. (2013). Which corporate sustainability activities are associated with greater financial payoffs?" Business Strategy and the Environment, 22(1), 49-61.

Lacoste, S. (2016). Sustainable value co-creation in business networks. Industrial Marketing Management, 52, 151-162.

López, M. V., Garcia, A., Rodriquez, L. (2007). Sustainable development and corporate performance: A study based on the Dow Jones Sustainability Index. Journal of Business Ethics, 75, 285-300.

Lubin, D.A., Esty, D.C., 2010. The sustainability imperative. Harvard Business Review 88, $42-50$.

Makkonen, H., \& Olkkonen, R. (2017). Interactive value formation in interorganizational relationships: Dynamic interchange between value co-creation, no-creation and codestruction. Marketing Theory, 17(4), 517-535

Meqdadi, O., Johnsen T.E., \& Johnsen, R.E. (2017). The role of power and trust in spreading sustainability initiatives across supply networks: A case study in the bio-chemical industry. Industrial Marketing Management, 62, 61-76.

Miles, M. B., Huberman, A. M., \& Saldana, J. (2014). Qualitative data analysis: A methods sourcebook ( $3^{\text {rd }}$ ed.). Los Angeles: Sage Publications.

Möller, K., \& Svahn, S. (2006). Role of knowledge in value creation in business nets. Journal of Management Studies, 43(5), 985-1007.

Nidumolu, R., Prahalad, C.K. \& Rangaswami, M.R (2009). Why sustainability is now the key driver of innovation. Harvard Business Review, 87(9), 56-64.

Ortiz-de-Mandojana, N. \& Bansal, P. (2016). The Long-term benefits of organizational resilience through sustainable business practices. Strategic Management Journal, 37(8): $1615-1631$.

Oruezabala, G., and Rico, J.-C. (2012). The impact of sustainable public procurement on supplier management - The case of French public hospitals. Industrial Marketing Management 41, 573-580.

Padgett, J., \& Powell, W. (2012). The Emergence of Organizations and Markets, Princeton University Press. 
Patala, S., Hämäläinen, S., Jalkala, A., Pesonen, H.-L., (2014). Towards a broader perspective on the forms of eco-industrial networks. Journal of Cleaner Production, 82, 166-178.

Patala, S., Jalkala, A., Keränen, J., Väisänen, S., Tuominen, V., \& Soukka, R. (2016). Sustainable value propositions: Framework and implications for technology suppliers. Industrial Marketing Management, 59, 144-156.

Peltola, T., Aarikka-Stenroos, L., Viana, E., \& Mäkinen, S. (2016). Value capture in business ecosystems for municipal solid waste management: Comparison between two local environments. Journal of Cleaner Production, 137, 1270-1279.

Pinho, N., Beirão, G., Patrício, L., \& Fisk, R. P. (2014). Understanding value co-creation in complex services with many actors. Journal of Service Management, 25(4), 470-493.

Plé, L. \& Chumpitaz Cáceres, R. (2010). Not always co-creation: introducing interactional codestruction of value in service-dominant logic. Journal of Services Marketing, 24(6), 430-437.

Porter, M.E. \& Kramer, M.R. (2006). The link between Competitive Advantage and Corporate Social Responsibility. Harvard Business Review, 78-94.

Porter, M. \& Kramer, M. (2011). Creating shared value. Harvard Business Review, 1-17.

Porter, M. \& Reinhardt, F. (2007). A strategic approach to climate change. Harvard Business Review, 10, 22-26.

Prior, D.D., \& Marcos-Cuevas, J. (2016). Value co-destruction in interfirm relationships: The impact of actor engagement styles. Marketing Theory, 16(4), 533-552.

Pressey, A. D., \& Vanharanta, M. (2016). Dark network tensions and illicit forbearance: Exploring paradox and instability in illegal cartels. Industrial Marketing Management, $55,35-49$.

Ranta, V., Aarikka-Stenroos, L., \& Mäkinen, S. (2018). Creating value in the circular economy: A structured multiple-case analysis of business models. Journal of Cleaner Production, 201, 988-1000.

Reypens, C, Lievens, A, \& Blazevic, V. (2016). Leveraging value in multi-stakeholder innovation networks: A process framework for value co-creation and capture. Industrial Marketing Management, 56 (40-50.

Ritvala, T. \& Salmi, A., (2010). Value-based network mobilization: A case study of modern environmental networkers. Industrial Marketing Management, 39, 898-907.

Ritvala, T., \& Salmi, A. (2011). Network mobilizers and target firms: The case of saving the Baltic Sea. Industrial Marketing Management 40, 887-898.

Scandelius, C., \& Cohen, G. (2016). Sustainability program brands: Platforms for collaboration and co-creation. Industrial Marketing Management, 57, 166-176.

Scholz, R. W. \& Tietje, O. (2002). Embedded Case Study Methods: Integrating Quantitative and Qualitative Knowledge. London: Sage Publications Inc. ISBN 0-7619-1946-5.

Seshadri, S. (2013). The sustainability syndicate: Shared responsibility in a transorganizational business model. Industrial Marketing Management, 42, 765-772.

Sharma, A., Iyer, G., Mehrotra, A., \& Krishnan, R. (2010). Sustainability and business-tobusiness marketing: A framework and implications. Industrial Marketing Management, $39,330-341$. 
Tate, W. L., Ellram, L. M., \& Gölgeci, I. (2013). Diffusion of environmental business practices: A network approach. Journal of Purchasing and Supply Management 19(4), 264-275.

Tidström, A. (2014). Managing tensions in coopetition. Industrial Marketing Management, 43(2), 261-271.

Tóth, Z., Peters, L.D., Pressey, A., \& Johnston, W.L. (2018). Tension in a value co-creation context: A network case study. Industrial Marketing Management. Forthcoming.

Vargo, S. L., \& Lusch, R. F. (2011). It's all B2B... and beyond: Toward a systems perspective of the market. Industrial Marketing Management, 40(2), 181-187.

Vargo, S.L. \& Lusch, R.F. (2016). Institutions and axioms: an extension and update of servicedominant logic. Journal of the Academy of Marketing Science, 44(5), 5-23.

Verleye, K., Jaakkola, E., Hodgkinson, I.R., Jun, G.T., Odekerken-Schröder, G. \& Quist, J. (2017). What causes imbalance in complex service networks? Evidence from a public health service, Journal of Service Management, 28(1), 34-56.

Wittneben, B.F., Okereke, C., Banerjee, S.B. \& Levy, D.L., (2012). Climate change and the emergence of new organizational landscapes. Organization Studies, 33(11), 1431-1450.

Yin, R. K. (2014) Case Study Research: Design and Methods (Fifth edition). Sage Publications Inc.: Thousand Oaks.

Öberg, C., Huge-Brodin, M. \& Björklund, M. (2012). Applying a network level in environmental impact assessment. Journal of Business Research, 65, 247-255. 